\begin{tabular}{l|l|l|l}
$\begin{array}{c}\text { Case Reports in } \\
\text { Demillatology }\end{array}$ & $\begin{array}{l}\text { Case Rep Dermatol 2011;3:5-7 } \\
\text { DOI: } 10.1159 / 000323863\end{array}$ & $\begin{array}{l}\text { Published online: } \\
\text { January 7, 2011 }\end{array}$ & $\begin{array}{l}\text { I 2011 S. Karger AG, Basel } \\
\text { ISSN 1662-6567 } \\
\text { www.karger.com/cde }\end{array}$ \\
\hline
\end{tabular}

\title{
The Perils of a Defective Medical Communication: Fatal Neglected Squamous Cell Carcinoma Arising in Perineal Hidradenitis Suppurativa
}

\author{
Calogero Pagliarello ${ }^{a}$ Andrea Paradisi ${ }^{b}$ \\ ${ }^{a}$ Health Services Research Unit, IDI-IRCCS, and b Department of Dermatology, \\ Catholic University of the Sacred Heart, Rome, Italy
}

\section{Key Words}

Squamous cell carcinoma $\cdot$ Hidradenitis suppurativa $\cdot$ Neglect

\begin{abstract}
Hidradenitis suppurativa (HS) is a recurrent suppurative disease characterized by inflammatory nodules, abscesses, fistulas, and scarring. We report a case of squamous cell carcinoma arising in chronic HS. In our case the asymptomatic lesion was neglected by the patient for a long time, allowing the occurrence of advanced disease before treatment was sought, which resulted in a terminal outcome. In the context of $\mathrm{HS}$, a painful lump or ulcer could easily be mistaken for an inflammatory lesion, and therefore a low threshold for biopsy is warranted.
\end{abstract}

\section{Introduction}

Hidradenitis suppurativa (HS) occurs commonly in the axilla, perineum, extragenitalia and inguinal regions. The etiology of HS remains unclear. Genetic factors, bacterial infection, abnormal host response, hormonal factors, glucose intolerance, obesity, smoking and disordered function of neutrophils may possibly lead to HS [1]. Clinical features show undermined sinus tracts and fistulae with suppurative exudates. HS is rarely complicated with squamous cell carcinoma (SCC), known as Marjolin's ulcer, in which the chronic long-standing inflammatory ulcer may result in malignant transformation. 


\begin{tabular}{c|l|l|l}
$\begin{array}{c}\text { Case Reports in } \\
\text { Demmatology }\end{array}$ & $\begin{array}{l}\text { Case Rep Dermatol 2011;3:5-7 } \\
\text { DOI: } 10.1159 / 000323863\end{array}$ & $\begin{array}{l}\text { Published online: } \\
\text { January 7, 2011 }\end{array}$ & $\begin{array}{l}\text { O 2011 S. Karger AG, Basel } \\
\text { ISSN 1662-6567 } \\
\text { www.karger.com/cde }\end{array}$ \\
\hline
\end{tabular}

\section{Case Report}

A 45-year-old man with a 30-year history of HS affecting both buttocks, groin and perianal regions presented with an ulcerated lesion on his right buttock (fig. 1a, b).

He was examined by a dermatologist for treating HS at the onset of disease, at the age of 15 . At that time, he was told that HS was an incurable condition, and he endured many years of recurrent abscesses treated by his general practitioner with prolonged courses of oral antibiotics. Thus, he treated the indurated plaque on his right buttock with a 10-week cycle of minocycline hydrochloride $100 \mathrm{mg}$ twice daily, reassured by a telephone consultation with his general practitioner. Due to the lack of improvement and a slight but continuous bleeding from the lesion, he consulted a dermatologist for an appropriate treatment. Incisional biopsy of the large, deeply fixed ulcer on the right buttock revealed a poorly differentiated SCC. There were enlarged palpable inguinal lymph nodes, and a CT scan showed multiple lung metastases. In view of the extent of the disease, surgery would not have been curative, and the patient was given palliative platinum-based chemotherapy. He died 9 months after the diagnosis of SCC.

\section{Discussion}

Several authors have emphasized the co-occurrence of HS and non-melanoma skin cancer $[2,3]$. Furthermore, SCCs arising in injured or chronically diseased skin are associated with a risk of metastasis that approaches $40 \%$ [4]. It has been postulated that chronic irritation and infection of long duration may lead to proliferative epidermal changes, including cancer.

In our patient, unlike other cases reported in the literature [2, 5], SCC clinical presentation was by no means deceptive. The malignant transformation was treated as an abscess in conformity with patient- and general practitioner-disease experience, and this diagnostic delay has proved fatal. The awareness that in the context of HS, a malignant lump or ulcer could develop and could be easily mistaken for an inflammatory lesion should always be provided to patients by any dermatologist.

Chronic diseases are frustrating for both patients and physicians. Moreover, very often patients do not easily accept the diagnosis and its implications, recurring to unnecessary consultations at the beginning of their disease, whereas afterwards they refuse to consult a dermatologist, disappointed by the 'hopeless attitude' they receive. While this lack of empowerment is devoid of fatal consequences in patients affected by diabetes or psoriasis, it seems highly advisable to promote self-efficacy in HS patients since the very first consultation. This need is deemed even more appropriate after the introduction of TNFalpha blockers for treating HS [6]. Our case serves as a pertinent reminder of the importance of supporting the patient's problem-solving skills in the early course of HS.

\section{Acknowledgements}

This study was supported by the Italian Ministry of Health within the Ricerca Corrente 2010, and it was financially supported in part by the 'Progetto Ricerca Corrente 2010' of the Italian Ministry of Health, Rome.

\section{Disclosure Statement}

The authors declare no conflict of interest. 


\begin{tabular}{c|l|l|l}
$\begin{array}{c}\text { Case Reports in } \\
\text { Demmatology }\end{array}$ & $\begin{array}{l}\text { Case Rep Dermatol 2011;3:5-7 } \\
\text { DOI: } 10.1159 / 000323863\end{array}$ & $\begin{array}{l}\text { Published online: } \\
\text { January 7, 2011 }\end{array}$ & $\begin{array}{l}\text { O 2011 S. Karger AG, Basel } \\
\text { ISSN 1662-6567 } \\
\text { www.karger.com/cde }\end{array}$ \\
\hline
\end{tabular}

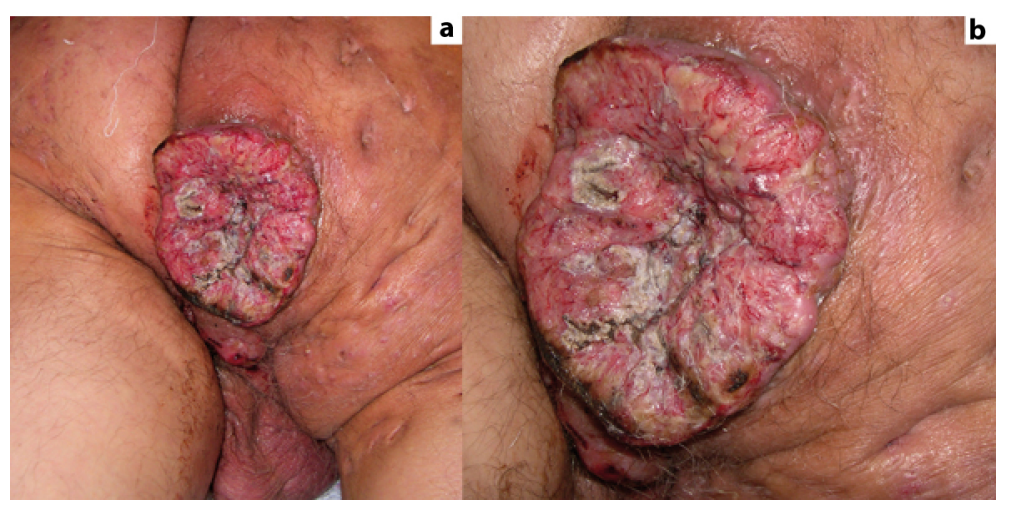

Fig. 1. Development of squamous cell carcinoma in areas affected by long-standing hidradenitis suppurativa (a). Close-up of the lesion (b).

\section{References}

1 Jemec GB: Hidradenitis suppurativa. J Cutan Med Surg 2003;7:47-56.

-2 Altunay IK, Gokdemir G, Kurt A, Kaiaoglu S: Hidradenitis suppurativa and squamous cell carcinoma. Dermatol Surg 2002;28:88-90.

-3 Lapins J, Ye W, Nyrén O, Emtestam L: Incidence of cancer among patients with hidradenitis suppurativa. Arch Dermatol 2001;137:730-734.

-4 Rowe DE, Carroll RJ, Day CL Jr: Prognostic factors for local recurrence, metastasis, and survival rates in squamous cell carcinoma of the skin, ear, and lip: implications for treatment modality selection. J Am Acad Dermatol 1992;26:976-990.

5 Shukla VK, Hughes LE: A case of squamous cell carcinoma complicating hidradenitis suppurativa. Eur J Surg Oncol 1995;21:106-109.

6 Maalouf E, Faye O, Poli F, Cosnes A, Revuz J: Fatal epidermoid carcinoma in hidradenitis suppurativa following treatment with infliximab. Ann Dermatol Venereol 2006;133:473-474. 